\title{
2021 Handbook of Florida Water Regulation: Northern Everglades and Estuaries Protection Program ${ }^{1}$
}

\author{
Michael T. Olexa, Tatiana Borisova, and Jana Caracciolo
}

\section{Preface}

This handbook is designed to provide an accurate, current, and authoritative summary of the principal federal and state (Florida) laws that directly or indirectly relate to agriculture. This handbook provides a basic overview of the many rights and responsibilities that farmers and farmland owners have under both federal and state laws as well as the appropriate contact information to obtain more detailed information. However, the reader should be aware that because the laws, administrative rulings, and court decisions on which this handbook is based are subject to constant revision, portions of this publication could become outdated at any time. Several details of cited laws are also left out due to space limitations. This handbook is provided as an educational text for those interested in water use and water resource issues in Florida.

This handbook is distributed with the understanding that the authors are not engaged in rendering legal or other professional advice, and the information contained herein should not be regarded as a substitute for professional advice. This handbook is not all inclusive in providing information to achieve compliance with the federal and state laws and regulations governing water protection. For these reasons, the use of these materials by any person constitutes an agreement to hold harmless the authors, the UF/IFAS Center for Agricultural and Natural Resource Law, and UF/IFAS Extension for any liability claims, damages, or expenses that may be incurred by any person as a result of reference to or reliance on the information contained in this handbook. Note: UF/IFAS is the acronym for University of Florida, Institute of Food and Agricultural Sciences.

\section{NEEPP Overview}

The primary goal of the Northern Everglades and Estuaries Protection Program (NEEPP) is to improve and protect the water quality and quantity in the Lake Okeechobee, Caloosahatchee River, and St. Lucie River watersheds (NEEPP, section 373.4595, Florida Statutes).

NEEPP is implemented in coordination with the Comprehensive Everglades Restoration Program (CERP, https:// www.nps.gov/ever/learn/nature/cerp.htm) to carry out the comprehensive goal of improving water quality in the Everglades, a unique wetland ecosystem that stretches from central Florida (Orlando area) all the way to the southern tip of the Florida peninsula. As the name suggests, NEEPP focuses on the northern portion of the Everglades that is roughly the area from Orlando to Belle Glade City, just south of Lake Okeechobee.

The Florida Legislature enacted NEEPP in 2007 to expand the existing Lake Okeechobee Protection Act to include protection for the entire Lake Okeechobee watershed

1. This document is FE610, one of a series of the Food and Resource Economics Department, UF/IFAS Extension. Original publication date October 1998. Revised June 2017 and April 2021. Visit the EDIS website at https://edis.ifas.ufl.edu for the currently supported version of this publication.

2. Michael T. Olexa, professor, Food and Resource Economics Department, and director, UF/IFAS Center for Agricultural and Natural Resource Law; Tatiana Borisova, associate professor, Food and Resource Economics Department; and Jana Caracciolo, student, Levin College of Law; UF/IFAS Extension, Gainesville, FL 32611.

The Institute of Food and Agricultural Sciences (IFAS) is an Equal Opportunity Institution authorized to provide research, educational information and other services

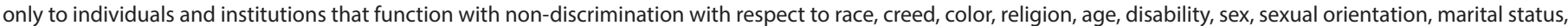

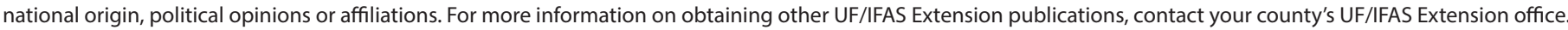
U.S. Department of Agriculture, UF/IFAS Extension Service, University of Florida, IFAS, Florida A \& M University Cooperative Extension Program, and Boards of County Commissioners Cooperating. Nick T. Place, dean for UF/IFAS Extension. 
(including Kissimmee River), along with the Caloosahatchee and St. Lucie Rivers and estuaries. Specifically, NEEPP created watershed protection programs for Lake Okeechobee, and the Caloosahatchee and St. Lucie Rivers (described below).

Under NEEPP, primary enforcement and regulatory power is vested in the South Florida Water Management District (SFWMD), the Florida Department of Environmental Protection (FDEP), and the Florida Department of Agriculture and Consumer Services (FDACS) to be performed in a cooperative fashion. While each entity is given specific tasks under NEEPP, they must consult with the other entities to coordinate regulation and enforcement.

Contact the individual agencies for more information on the requirements of SFWMD, FDEP, and FDACS under NEEPP. For additional overview information on NEEPP, visit the FDEP website (http://www.dep.state.fl.us/everglades/neepp.htm).

\section{Creative Public-Private Partnerships and Programs}

According to NEEPP, the development of creative publicprivate partnerships and programs are encouraged to facilitate or further the restoration of the surface water resources of the Lake Okeechobee watershed, the Caloosahatchee River watershed, and the St. Lucie River watershed. An example of such creative partnership can be programs for water storage and quality improvement on private lands.

In line with this legislative intention, SFWMD is involved with the following programs: Dispersed Water Management (to encourage private property owners to retain water on their land to manage stormwater runoff); Northern Everglades-Payment for Ecosystem Services (to achieve water storage, water quality, and habitat improvements on private lands); and Water Farming (to store excess surface water on privately owned fallow citrus lands). More information about public-private partnership programs and opportunities can be found at the SFWMD website (https://www. sfwmd.gov/our-work/water-storage-strategies).

\section{The Lake Okeechobee Watershed Protection Program}

The Lake Okeechobee Watershed Protection Program was created to improve the hydrology and water quality through phosphorus load reductions in Lake Okeechobee watershed, including Kissimmee River, Fisheating Creek,
Taylor Creek / Nubbin Slough, Everglades Agricultural Area, and other areas (NEEPP, 373.4595, Florida Statutes). The program includes four main components: the Lake Okeechobee Watershed Plan, Lake Okeechobee Basin Management Action Plan, Lake Okeechobee Exotic Species Control Program, and Lake Okeechobee Internal Phosphorus Management Program.

\section{The Lake Okeechobee Watershed Protection Plan}

SFWMD, in cooperation with FDEP and FDACS, is required to develop the Lake Okeechobee Watershed Protection Plan. Beginning March 1, 2020, and every 5 years thereafter, the District must update the Plan (https:// www.sfwmd.gov/lowpp).

The Lake Okeechobee Watershed Protection Plan has two main parts: Lake Okeechobee Watershed Construction Project (which includes Phase I and Phase II) and the Lake Okeechobee Watershed Research and Water Quality Monitoring Program.

\section{LAKE OKEECHOBEE WATERSHED CONSTRUCTION PROJECT (LOWCP)}

NEEPP required that SFWMD, in coordination with FDEP, design and construct LOWCP, in an effort to improve the hydrology and water quality of Lake Okeechobee and downstream receiving waters.

Phase I of LOWCP requires phosphorus load reductions through the construction of stormwater treatment facilities and isolated wetland restoration projects. An example of a Phase I project is the construction of the Taylor Creek and Nubbin Slough Stormwater Treatment Area, which was designed to remove two tonnes of total phosphorus per year from the Taylor Creek basin, part of the Lake Okeechobee watershed. This stormwater treatment area was a Congressionally approved Critical Restoration Project implemented in partnership with the federal government (see more in Berlotti et al. 2014).

Phase II of LOWCP requires measures for the construction of additional facilities for the improvement of the quality, quantity, timing, and distribution of water in the northern Everglades. According to SFWMD, the main components of Phase II are:

- Implementing agricultural best management practices

- Constructing treatment wetlands to clean water flowing into Lake Okeechobee 
- Adopting new regulations to improve water quality and flow

- Creating water storage north of Lake Okeechobee through a combination of above-ground reservoirs, underground storage, and alternate water storage projects

NEEPP requires LOWCP and any structures discharging into or from Lake Okeechobee to obtain a Lake Okeechobee Protection Permit. This permit is a type of Environmental Resource Permit according to Rule 62330.485, Florida Administrative Code (F.A.C.). See more on this topic at https://floridadep.gov/eco-pro/eco-pro/ content/permitting.

For more information on LOWCP, visit the SFWMD website (https://www.sfwmd.gov/lowcp).

\section{LAKE OKEECHOBEE WATERSHED RESEARCH AND WATER QUALITY MONITORING PROGRAM}

Under NEEPP, the SFWMD, FDEP, and FDACS were required to establish the Lake Okeechobee Research and Water Quality Monitoring Program. The Program evaluates the volume and timing of water flow from the watershed to the estuaries. Among other requirements, the Program directs the coordinating agencies to:

- Analyze all available existing water quality data regarding total phosphorus in the Lake Okeechobee watershed

- Conduct an assessment of the water volumes and timing from the Lake Okeechobee watershed and the timing and volume of water delivered to the estuaries

- Determine the relative contribution of phosphorus from all identifiable sources and all primary and secondary land use

- Develop a water quality baseline to represent existing conditions for total phosphorus

- Develop a Lake Okeechobee water quality model that reasonably represents the phosphorus dynamics of Lake Okeechobee and incorporates an uncertainty analysis associated with model predictions

- Evaluate the feasibility of alternative nutrient reduction technologies, including sediment traps, canal and ditch maintenance, aquaculture, bioenergy conversion processes, and algal or other biological treatment technologies

- Monitor long-term ecological changes

- Measure compliance with water quality standards for total phosphorus

\section{The Lake Okeechobee Basin Management Action Plan}

The two components of the Lake Okeechobee Watershed Plan-the Construction Project and the Research and Water Quality Monitoring_provide the basis for the Lake Okeechobee Basin Management Action Plan (BMAP) which aims at achieving water quality standards and controlling phosphorus loading to Lake Okeechobee and its tributaries.

The Lake Okeechobee BMAP is a multifaceted approach designed to achieve the total maximum daily load (TMDL) goals by improving the management of phosphorus sources within the Lake Okeechobee watershed. Note that TMDLs refer to the maximum pollution discharge limits, and BMAPs refer to the plans to reduce pollution to the limits specified in the TMDL (see FE608, FWRA). The relevant agencies may accomplish this goal by implementing regulations and best management practices, improving natural hydrological function, and using alternative technologies.

For agriculture specifically, FDACS takes the lead on agricultural interim measures, best management practices, and other measures. Agricultural producers shall either implement best management practices or demonstrate compliance with state water quality standards (by water quality monitoring). SFWMD or FDEP must conduct monitoring to verify the effectiveness of agricultural best management practices. If water quality problems are detected despite the appropriate implementation of adopted best management practices, a reevaluation of the best management practices must be conducted, and the rule must be revised to require implementation of the modified practice. FDACS, in cooperation with SFWMD and FDEP, are required to provide technical and financial assistance for implementation of agricultural best management practices, subject to the availability of funds.

\section{Lake Okeechobee Exotic Species Control Program}

The program focuses on identifying the exotic species that threaten the native plant and animal life within the Lake Okeechobee watershed, and developing and implementing protective measures.

\section{Lake Okeechobee Internal Phosphorus Management Program}

Phosphorus loading to the waters of Lake Okeechobee can come from a variety of sources, including internal sources such as the lake's sediment. SFWMD, in cooperation with 
the other agencies and interested parties, is charged with evaluating the feasibility of Lake Okeechobee internal phosphorus load removal projects. Reasonable methods of phosphorus removal should be considered, and their technical and economic characteristics should be examined. If methods are found to be feasible, SFWMD shall immediately pursue the design, funding, and permitting for their implementation.

\section{Caloosahatchee River and St. Lucie River Watershed Protection Programs}

The Caloosahatchee River and St. Lucie River Watershed Protection Programs are intended to address the reduction of pollutant loadings, restoration of natural hydrology, and compliance with applicable state water quality standards (NEEPP, section 373.4595, Florida Statutes). Water pollution problems are associated with phosphorus and nitrogen loading; hence, many of the plans, programs, and projects are intended to address both nutrients.

The Programs have the same structure as the Lake Okeechobee Watershed Protection Program. The Caloosahatchee and St Lucie Rivers each have their own Watershed Protection Plans (Construction Projects, and the Research and Water Quality Monitoring Program), and Basin Management Action Plans. The programs have the same functions as the ones for the Lake Okeechobee Watershed Protection Program.

\section{Sources}

Chapter 373, Florida Statutes, Sections 373.451 to 373.459 and 373.4595

FDEP, Northern Everglades and Estuaries Protection Program, https://floridadep.gov/eco-pro/eco-pro/content/ northern-everglades-and-estuaries-protection-programneepp

SFWMD, Northern Everglades and Estuaries Protection Program, https://www.sfwmd.gov/our-work/ northern-everglades

SFWMD, South Florida Environmental Report, https://apps. sfwmd.gov/sfwmd/SFER/2021_sfer_final/sfer_toc_v1.pdf

SFWMD, Water Storage Strategies, https://www.sfwmd.gov/ our-work/water-storage-strategies

\section{Acknowledgments}

The authors are indebted to the personnel of both state and federal agencies who provided their time and advice in the preparation of this handbook. We acknowledge Carol Fountain and Susan Gildersleeve at the University of Florida for their assistance in editing this handbook. We also acknowledge funding received for updating this publication from the James S. and Dorothy F. Wershow Agricultural Law Endowment. 